\title{
OBSERVATIONS RELATED TO THE AETIOLOGY OF PLACENTA PRAEVIA

\author{
WITH SPECIAL REFERENCE TO THE INFLUENCE \\ OF AGE AND PARITY
}

BY

\author{
R. G. RECORD \\ From the Department of Social Medicine, University of Birmingham
}

It is generally accepted that the frequency of placenta praevia is higher among multigravidae than among primigravidae. This observation has prompted the suggestion that low implantation of the ovum is a result of functional or structural changes in the uterus resulting from repeated pregnancies (Solomons and Canter, 1932; Davis and Campbell, 1946; Shaw, 1947; Findley, 1951). It is possible, however, that the association of placenta praevia with parity is secondary to its association with age, a result which would have different implications in respect of aetiology.

It is surprising that this possibility has received little attention. Penrose (1939) analysed a small series (72 cases) using a modification of the Greenwood-Yule method. He concluded that increasing maternal age is significant in central placenta praevia, and suggested that in non-central cases multiparity may be more important. These conclusions cannot be accepted unreservedly since a number of mothers had not reached the end of the reproductive period. Use of the Greenwood-Yule method in these circumstances is likely to give a false impression of the importance of increasing parity or maternal age. (This subject has received fuller consideration elsewhere-McKeown and Record, 1956). Kalmus (1946) compared a larger series (162 cases) with a random sample of hospital births and came to conclusions similar to those of Penrose. The control group was not entirely satisfactory, however, since hospital deliveries as a whole contain an abnormally high proportion of primiparae. No selection is applied to admission of cases of placenta praevia, which may therefore show an apparent association with multiparity.

It appears that a more reliable assessment of the relative importance of age and parity in placenta praevia would be useful, and that the suggestion that there is a sharp aetiological distinction between central and non-central types requires investigation. The present inquiry has been undertaken with this object. The method used was a comparison between a large series of cases of placenta praevia and a control group of births selected at random from the population in which the cases occurred. Also considered were the association with twinning and congenital malformations and the incidence of previous abortions and of ante-partum haemorrhage.

\section{Material}

An attempt was made to collect details of all cases of placenta praevia delivered in Birmingham during the years 1942-52 by inspecting the records of five maternity hospitals and two general hospitals containing large maternity units. For the years 1946-51 records appeared to be complete, but case notes in several of the smaller hospitals were not available for some of the other years. It is not likely that the omission of these cases has introduced any bias into the series since their number could not be large and there is no reason to suppose that they were unrepresentative. The data abstracted from the hospital records included patient's age, number and result of previous pregnancies, date of last menstrual period preceding relevant pregnancy, date of delivery, type of placenta praevia, and weight, condition, and fate of the foetus.

A control series of 1,156 births representative of all births to Birmingham residents during the years 1942-52 had been assembled for an earlier investigation (Smith and Record, 1955). The data included maternal age and number of previous pregnancies.

\section{RESULTS}

Classification.-Assembling a series of cases of placenta praevia from a number of sources presents some difficulty on account of the diversity of systems of classification in common use. Much confusion may be caused by the use of the terms "lateral" and "marginal", which indicate the position of the 
placenta relative to the lower segment in one system and to the internal os in another. Thus a low-lying placenta and a placenta praevia of intermediate type might be termed respectively "lateral" and "marginal" by one obstetrician, and "marginal" and "lateral" by another. Even in the same hospital the method of classification was not always uniform. The system most widely used was that advocated by Browne (1937) and with a slight modification it has been adopted in this inquiry. It was usually possible to assign cases described in other terms to the appropriate group of Browne's classification. In a few doubtful cases the less severe of the alternatives was chosen. Occasionally no classification could be made because the data were inadequate. No attempt was made to separate Types 3 and 4 , since the distinction is a fine one and cannot be made with confidence unless the internal os is well dilated.

Records of 1,023 patients considered to have placenta praevia were obtained. Their classification according to type of disease is shown in Table I.

TABLE I

CASES OF PLACENTA PRAEVIA TREATED IN BIRMINGHAM HOSPITALS (1942-52)

\begin{tabular}{|c|c|c|c|c|c|c|}
\hline \multirow{3}{*}{$\begin{array}{c}\text { Type of } \\
\text { Placenta Praevia }\end{array}$} & \multicolumn{4}{|c|}{ Place of Residence } & \multirow{2}{*}{\multicolumn{2}{|c|}{ Total }} \\
\hline & \multicolumn{2}{|c|}{ Birmingham } & \multicolumn{2}{|c|}{$\begin{array}{c}\text { Outside } \\
\text { Birmingham }\end{array}$} & & \\
\hline & No. & $\begin{array}{l}\text { Per } \\
\text { cent. }\end{array}$ & No. & $\begin{array}{l}\text { Per } \\
\text { cent. }\end{array}$ & No. & $\begin{array}{c}\text { Per } \\
\text { cent. }\end{array}$ \\
\hline $\begin{array}{l}1 \text { (placenta extends into } \\
\text { lower segment) }\end{array}$ & 294 & $39 \cdot 3$ & 107 & $38 \cdot 9$ & 401 & $39 \cdot 2$ \\
\hline $\begin{array}{l}2 \text { (placenta extends to } \\
\text { edge of internal os). }\end{array}$ & 216 & $28 \cdot 9$ & 82 & $29 \cdot 8$ & 298 & $29 \cdot 1$ \\
\hline $\begin{array}{l}3 \text { and } 4 \text { (placenta parti- } \\
\text { ally or completely } \\
\text { covers internal os).. }\end{array}$ & 202 & $27 \cdot 0$ & 81 & $29 \cdot 5$ & 283 & $27 \cdot 7$ \\
\hline Unspecified .. & 36 & $4 \cdot 8$ & 5 & $1 \cdot 8$ & 41 & $4 \cdot 0$ \\
\hline Total .. & 748 & 100 & 275 & 100 & 1,023 & 100 \\
\hline
\end{tabular}

INCIDENCE.-Estimation of incidence is based on the assumption that all patients with placenta praevia are admitted to hospital for delivery. Of the 1,023 cases, 275 who lived outside Birmingham came from an ill-defined area for which the total number of births could not be estimated. The remaining 748 were Birmingham residents and can be related to a known population of births. Since ascertainment was known to be incomplete for the years 1942-5 and for 1952, the estimate of incidence is based on 496 cases which occurred in the six years 1946-51. The total number of Birmingham confinements during this period is not precisely known since the Registrar-General records only the number of births
$(129,348$ including stillbirths), but it can be estimated by assuming that one confinement in eighty results in twins. The number of confinements is thus presumed to be 127,751, giving an incidence of placenta praevia of 3.9 per 1,000 . When applied to the relative frequencies given in Table $I$, this figure gives the incidence per 1,000 confinements as $1 \cdot 6$ for Type $1,1 \cdot 2$ for Type 2 , and $1 \cdot 1$ for Types 3 and 4 .

The only previous attempt in recent years to estimate incidence of placenta praevia in a general population appears to be that of Hauch (cited by Davis, 1936) who obtained a value of 2.07 per 1,000 births in Denmark. Incidence among hospital confinements has been estimated many times. Figures vary considerably, ranging from 2.6 (per 1,000 deliveries) in a group of Stockholm hospitals (Westgren, 1954) to 11.9 in Siena (Rizzuti, 1947). These values, of course, reflect the extent to which domiciliary midwifery is practised in the area rather than the incidence of placenta praevia in the population.

Relative Influence of Age and Parity.-Patients admitted to Birmingham hospitals who normally lived outside the city could not be related to a known population and are excluded from the examination of age and parity. Among Birmingham patients of known age and parity there were 289 cases of Type 1, 210 of Type 2, and 197 of Types 3 and 4 . Cases of unspecified type were not used. Parity was calculated from the numbers of previous viable pregnancies, abortions being excluded.

By comparing the distribution by age and parity of the control group (Table II) with that of each type of placenta praevia, relative incidences in the various age-parity groups were obtained (Table III, opposite).

TABLE II

CONTROL GROUP DISTRIBUTED ACCORDING TO AGE AND PARITY

\begin{tabular}{|c|c|c|c|c|c|}
\hline \multirow{2}{*}{\multicolumn{2}{|c|}{ Age Group }} & \multicolumn{3}{|c|}{ Parity } & \multirow{2}{*}{$\begin{array}{c}\text { All } \\
\text { Parities }\end{array}$} \\
\hline & & 1 & 2 and 3 & 4 and over & \\
\hline $\begin{array}{l}\text { Under } 25 \\
25-\ldots \\
30-\end{array}$ & $\begin{array}{l}\ldots \\
\cdots \\
\cdots\end{array}$ & $\begin{array}{r}200 \\
126 \\
46 \\
25\end{array}$ & $\begin{array}{r}125 \\
187 \\
159 \\
79\end{array}$ & $\begin{array}{r}2 \\
42 \\
68 \\
97\end{array}$ & $\begin{array}{l}327 \\
355 \\
273 \\
201\end{array}$ \\
\hline All Ages & .. & 397 & 550 & 209 & 1,156 \\
\hline
\end{tabular}

The significance of the trends was assessed by the method devised by Yates (1948).

In Type 1 placenta praevia, incidence appears to increase with both age and parity. When the trends are examined within fixed age and parity groups, the only significant ones are an increase with maternal age among primiparae, and an 
TABLE III

RELATIVE INCIDENCE ACCORDING TO AGE AND PARITY TYPE 1

\begin{tabular}{|c|c|c|c|c|c|c|}
\hline \multirow{2}{*}{$\begin{array}{l}\text { Age } \\
\text { Group }\end{array}$} & \multicolumn{3}{|c|}{ Parity } & \multirow{2}{*}{$\underset{\text { Parities }}{\text { All }}$} & \multirow[b]{2}{*}{$\chi^{2}$} & \multirow[b]{2}{*}{$P$} \\
\hline & 1 & 2 and 3 & $\begin{array}{l}4 \text { and } \\
\text { over }\end{array}$ & & & \\
\hline $\begin{array}{l}\text { Under }_{25} \\
-\end{array}$ & $\begin{array}{l}0 \cdot 7 \\
(34)\end{array}$ & $\begin{array}{l}0 \cdot 7 \\
(22)\end{array}$ & $\overline{(2)}$ & $\begin{array}{l}0.7 \\
(58)\end{array}$ & $1 \cdot 33$ & 0.25 \\
\hline $25-$ & $\begin{array}{l}0.6 \\
(19)\end{array}$ & $\begin{array}{l}1 \cdot 0 \\
(46)\end{array}$ & $\begin{array}{l}2 \cdot 0 \\
(21)\end{array}$ & $\begin{array}{l}1 \cdot 0 \\
(86)\end{array}$ & $10 \cdot 70$ & 0.001 \\
\hline 30 & $\begin{array}{l}1 \cdot 2 \\
(14)\end{array}$ & $\begin{array}{l}0 \cdot 8 \\
(30)\end{array}$ & $\begin{array}{l}1 \cdot 3 \\
(22)\end{array}$ & $\begin{array}{l}1 \cdot 0 \\
(66)\end{array}$ & 0.20 & 0.65 \\
\hline $\begin{array}{l}35 \text { and } \\
\text { over }\end{array}$ & $\begin{array}{l}2 \cdot 1 \\
(13)\end{array}$ & $\begin{array}{l}1 \cdot 1 \\
(22)\end{array}$ & $\begin{array}{l}1 \cdot 8 \\
(44)\end{array}$ & $\begin{array}{l}1 \cdot 6 \\
(79)\end{array}$ & $0 \cdot 13$ & 0.72 \\
\hline All Ages & $\begin{array}{l}0.8 \\
(80)\end{array}$ & $\begin{array}{l}0.9 \\
(120)\end{array}$ & $\begin{array}{l}1 \cdot 7 \\
(89)\end{array}$ & $\begin{array}{l}1 \cdot 0^{*} \\
(289)\end{array}$ & $16 \cdot 66$ & $<0.0001$ \\
\hline$\chi^{2}$ & $8 \cdot 47$ & 0.72 & 0.03 & $15 \cdot 03$ & & \\
\hline$\ldots$ & 0.004 & 0.40 & 0.86 & 0.0001 & & \\
\hline
\end{tabular}

* Age and parity unknown in five cases

TYPE 2

\begin{tabular}{|c|c|c|c|c|c|c|}
\hline \multirow{2}{*}{$\begin{array}{c}\text { Age } \\
\text { Group }\end{array}$} & \multicolumn{3}{|c|}{ Parity } & \multirow{2}{*}{$\begin{array}{c}\text { All } \\
\text { Parities }\end{array}$} & \multirow[b]{2}{*}{$\chi^{2}$} & \multirow[b]{2}{*}{$P$} \\
\hline & 1 & 2 and 3 & $\begin{array}{l}4 \text { and } \\
\text { over }\end{array}$ & & & \\
\hline $\begin{array}{r}\text { Under } \\
25-\end{array}$ & $\begin{array}{l}0.4 \\
(15)\end{array}$ & $\begin{array}{l}0.5 \\
(11)\end{array}$ & $\overline{(1)}$ & $\begin{array}{l}0.5 \\
(27)\end{array}$ & 0.33 & 0.57 \\
\hline $25-$ & $\begin{array}{l}0.5 \\
(12)\end{array}$ & $\begin{array}{l}0.9 \\
(29)\end{array}$ & $\begin{array}{r}0 \cdot 8 \\
\text { (6) }\end{array}$ & $\begin{array}{l}0.7 \\
(47)\end{array}$ & $1 \cdot 19$ & 0.27 \\
\hline 30 & $\begin{array}{l}1 \cdot 2 \\
(10)\end{array}$ & $\begin{array}{l}1.4 \\
(40)\end{array}$ & $\begin{array}{l}1 \cdot 2 \\
(15)\end{array}$ & $\begin{array}{l}1 \cdot 3 \\
(65)\end{array}$ & 0.002 & $>0.95$ \\
\hline $\begin{array}{l}35 \text { and } \\
\text { over }\end{array}$ & $\begin{array}{r}1.8 \\
(8)\end{array}$ & $\begin{array}{l}2 \cdot 5 \\
(36)\end{array}$ & $\begin{array}{l}1 \cdot 5 \\
(27)\end{array}$ & $\begin{array}{l}1.9 \\
(71)\end{array}$ & 0.93 & 0.33 \\
\hline${ }_{\text {All }}$ & $\begin{array}{l}0.6 \\
(45)\end{array}$ & $\begin{array}{l}1 \cdot 2 \\
(116)\end{array}$ & $\begin{array}{l}1 \cdot 3 \\
(49)\end{array}$ & $\begin{array}{l}1 \cdot 0 \dagger \\
(210)\end{array}$ & $11 \cdot 87$ & 0.001 \\
\hline $\begin{array}{ll}x^{2} & \ldots\end{array}$ & 11.95 & $26 \cdot 05$ & 1.59 & $47 \cdot 64$ & & \\
\hline$\ldots$ & 0.001 & $<0.0001$ & 0.21 & $<0.0001$ & & \\
\hline
\end{tabular}

t Age and parity unknown in six cases

TYPES 3 and 4

\begin{tabular}{|c|c|c|c|c|c|c|}
\hline \multirow{2}{*}{$\begin{array}{c}\text { Age } \\
\text { Group }\end{array}$} & \multicolumn{3}{|c|}{ Parity } & \multirow{2}{*}{$\begin{array}{c}\text { All } \\
\text { Parities }\end{array}$} & \multirow[b]{2}{*}{$x^{2}$} & \multirow[b]{2}{*}{$P$} \\
\hline & 1 & 2 and 3 & $\begin{array}{l}4 \text { and } \\
\text { over }\end{array}$ & & & \\
\hline$\underset{25-}{\text { Under }}$ & $\begin{array}{r}0 \cdot 2 \\
(7)\end{array}$ & $\begin{array}{r}0.4 \\
(8)\end{array}$ & $\overline{(1)}$ & $\begin{array}{l}0 \cdot 3 \\
(16)\end{array}$ & $1 \cdot 93$ & $0 \cdot 16$ \\
\hline 25 & $\begin{array}{l}0.7 \\
(15)\end{array}$ & $\begin{array}{l}0.8 \\
(27)\end{array}$ & $\begin{array}{r}1.0 \\
(7)\end{array}$ & $\begin{array}{l}0 \cdot 8 \\
(49)\end{array}$ & 0.55 & 0.46 \\
\hline 30 & $\begin{array}{l}1 \cdot 3 \\
(10)\end{array}$ & $\begin{array}{l}1 \cdot 3 \\
(36)\end{array}$ & $\begin{array}{l}1 \cdot 0 \\
(12)\end{array}$ & $\begin{array}{l}1 \cdot 2 \\
(58)\end{array}$ & $0 \cdot 25$ & 0.62 \\
\hline $\begin{array}{l}35 \text { and } \\
\text { over }\end{array}$ & $\begin{array}{l}2 \cdot 3 \\
(10)\end{array}$ & $\begin{array}{l}1 \cdot 9 \\
(26)\end{array}$ & $\begin{array}{l}2 \cdot 3 \\
(38)\end{array}$ & $\begin{array}{l}2 \cdot 2 \\
(74)\end{array}$ & 0.005 & $>0.95$ \\
\hline${ }_{\text {Ages }}$ & $\begin{array}{l}0.6 \\
(42)\end{array}$ & $\begin{array}{l}1 \cdot 0 \\
(97)\end{array}$ & $\begin{array}{l}1.6 \\
(58)\end{array}$ & $\begin{array}{l}1 \cdot 0 \ddagger \\
(197)\end{array}$ & $19 \cdot 79$ & $<0.0001$ \\
\hline $\begin{array}{lll}x^{2} & \ldots\end{array}$ & $28 \cdot 16$ & $19 \cdot 05$ & $5 \cdot 23$ & $64 \cdot 23$ & & \\
\hline $\begin{array}{ll}\boldsymbol{P} & \ldots\end{array}$ & $<0.0001$ & $<0.0001$ & 0.02 & $<0.0001$ & & \\
\hline
\end{tabular}

‡ Age and parity unknown in five cases

Numbers of cases shown in brackets increase with parity in women aged 25-29. In Type 2 and Types 3 and 4 the same association with both age and parity is exhibited by the totals. When attention is confined to fixed age and parity groups, incidence increases consistently with age but is unrelated to parity.

FERTILITY.-The report of a joint committee of the Royal College of Obstetricians and Gynaecologists and the British Paediatric Association on neonatal mortality and morbidity (1949) stated that the incidence of placenta praevia is thought to be relatively high in women who have had many pregnancies at short intervals. Eastman (1950) also mentions rapidity of child-bearing as a possible aetiological factor. No controlled study appears to have been attempted and the present inquiry provides only indirect evidence on this point. It seems reasonable to expect that, if patients with placenta praevia have had previous children at relatively short intervals, they would have attained a higher parity at a given age than normal mothers. In these circumstances there would be an association between incidence and parity when age is held constant. The fact that no such trend is revealed (except for Type 1 cases aged 25-29) suggests that the fertility of patients with placenta praevia is not abnormal.

INCIDENCE OF TwINNING.-There were nineteen twin pregnancies in the total series of 1,023 cases of placenta praevia. This incidence $(1.86$ per cent.) is greater than that in the general population (the frequency of twin maternities in England and Wales during 1938-48 was $1 \cdot 22$ per cent.: Waterhouse, 1950), but part of the difference can be explained by the fact that twinning is more likely at the ages when placenta praevia is most common. Standardization of the national rates quoted by Waterhouse to the age and parity distribution of the placenta praevia cases raises the frequency of twin maternities in the population to 1.35 per cent.; this frequency differs from that in the placenta praevia series by $0.51 \pm 0.37$ per cent. Although not significant this difference is not likely to be a chance occurrence since an increased frequency of twinning in placenta praevia has previously been recorded a number of times. This means, of course, that the incidence of placenta praevia is higher in twin than in single pregnancies. But this is probably not a matter of much aetiological importance; it may merely reflect the fact that in most twin gestations there are two placentae.

Sex Ratio.-Of the 1,042 infants in the series, sex was recorded for 1,$004 ; 534$ (53.19 per cent.) were males. The sex ratio of all births in England and 
Wales for the same period was $51 \cdot 54$ per cent. Although the difference $(1 \cdot 65 \pm 1 \cdot 58)$ is too small to attract much attention, it is worth noting that Wesselink (1922) also found a raised sex ratio in placenta praevia $(55.4$ per cent. males in a series of 980). A possible explanation of this finding is considered below.

InCIDENCE OF MAJor Congenital MalformaTIONS.-Malformations of the extremities, infantile pyloric stenosis, hernias, and naevi have been excluded from consideration. Records were complete for 1,004 infants; major malformations were noted in 22 , in three of which two systems were involved. There were therefore 25 malformations in the series, giving an incidence of 2.49 per cent. (Table IV).

TABLE IV

INCIDENCE OF MAJOR CONGENITAL MALFORMATIONS

\begin{tabular}{|c|c|c|}
\hline $\begin{array}{c}\text { Type of } \\
\text { Malformation }\end{array}$ & $\begin{array}{l}\text { Number in } \\
1,004 \text { Cases } \\
\text { of Placenta } \\
\text { Praevia }\end{array}$ & $\begin{array}{l}\text { Estimated Incidence in All Births } \\
\text { (per } 1,000)\end{array}$ \\
\hline $\begin{array}{c}\text { Of central nervous } \\
\text { system.. } \quad . .\end{array}$ & 12 & $\begin{array}{c}6.94 \text { (Record and McKeown, } \\
1949)\end{array}$ \\
\hline $\begin{array}{rr}\begin{array}{c}\text { Congenital } \\
\text { disease... }\end{array} & \text { heart } \\
\end{array}$ & 5 & $\begin{array}{c}\text { 3.17 (MacMahon, McKeown } \\
\text { and Record, 1953) }\end{array}$ \\
\hline Exomphalos & 3 & $\begin{array}{c}0 \cdot 31 \text { (McKeown, MacMahon } \\
\text { and Record, 1953) }\end{array}$ \\
\hline $\begin{array}{c}\text { Hare lip and/or } \\
\text { Cleft palate } \ldots\end{array}$ & 2 & $\begin{array}{l}1 \cdot 30 \text { (MacMahon and } \\
\text { McKeown, 1953) }\end{array}$ \\
\hline $\begin{array}{c}\text { Of genito-urinary } \\
\text { tract } \ldots \quad \ldots\end{array}$ & 2 & 0.06 (Murphy, 1947) \\
\hline $\begin{array}{l}\text { Of gastro-intesti- } \\
\text { nal tract (exclu- } \\
\text { ding pyloric } \\
\text { stenosis) }\end{array}$ & 0 & 0.44 (Murphy, 1947) \\
\hline Mongolism & 1 & $1.60\left(\begin{array}{c}\text { Carter } \\
1951)\end{array}\right.$ and MacCarthy, \\
\hline Other & 0 & 0.29 (Murphy, 1947) \\
\hline Total & 25 & $14 \cdot 11$ \\
\hline
\end{tabular}

The incidence in all births was estimated (from published data relating to previous Birmingham inquiries combined with data from other sources) to be 1.41 per cent. Thus the excess of malformations in the placenta praevia series is $1.08 \pm 0.37$ per cent. This result supports the view of Greenhill $(1923,1939)$ that there is an association between placenta praevia and congenital malformations. The association is particularly marked in the case of anencephalus which accounted for seven of the 25 malformations in the present series (28 per cent.). The same percentage was shown by Greenhill's data (nineteen anencephalics in 67 malformations), and identical figures (nineteen in 67) were obtained by combining data from four other sources
(Aigner, 1940; Macafee, 1945; Murphy, 1947; Tennent, 1947). Altogether, therefore, we have information on 159 malformations associated with placenta praevia; $45(28.3$ per cent.) of these were anencephalics. This percentage is $12.0 \pm 2.9$ in excess of the expected figure $(16 \cdot 3$ per cent.) derived by relating the incidence of anencephalus in all births $(2 \cdot 3$ per 1,000-Record and McKeown, $1949)$ to the estimated incidence of all major malformations $(14 \cdot 1$ per 1,000$)$.

This observation offers a possible explanation for the raised sex ratio of infants in cases of placenta praevia. It is well known that the sex ratio of anencephalus is low, and there is evidence that it is particularly low when pregnancy terminates unusually early (MacMahon and McKeown, 1952). When placenta praevia and anencephalus are associated, the pregnancy is likely to terminate early (for the six cases in which the data were available mean duration of gestation was 31 weeks). A number of foetuses, mainly female, may be lost at a stage when neither placenta praevia nor anencephalus is recognized. A series of cases of placenta praevia coming to medical attention may therefore be expected to show a slightly raised sex ratio.

InCidence of Previous Abortions.-Adequate histories were available for 987 cases of placenta praevia (all types). These patients had had 1,994 previous pregnancies, of which $198(9.9$ per cent.) had aborted. It is not easy to find an acceptable control group with which this figure can be compared. The case notes of a consecutive series of 2,957 multigravidae delivered in the Birmingham Maternity Hospital recorded 1,044 abortions in 6,521 previous pregnancies. This incidence (16 per cent.) is likely to be greater than that in the general population since selection of cases for delivery in hospital is undoubtedly influenced by the previous obstetric history. A more satisfactory group for comparison, perhaps, is that derived from a survey of all births in the County Borough of Smethwick in the period April, 1949, to March, 1950. The results of previous pregnancies were recorded antenatally by an obstetrician or midwife, and data from $\mathbf{7 8 0}$ multigravidae were obtained. The total number of previous pregnancies was 1,640 , of which 115 ( 7.0 per cent.) aborted. This is significantly less than the incidence in the previous pregnancies of patients with placenta praevia, but the difference $(2.9$ per cent.) is small. It seems reasonable to conclude that the present inquiry provides little support for the view of Binder (1934) that previous abortion is unusually common in patients with placenta praevia. 
RECURRENCE.-Of the 987 patients with placenta praevia for whom reliable histories were available, ten reported placenta praevia in a previous pregnancy (five of these earlier cases are included in the present series). A history of previous antepartum haemorrhage of unspecified type was given by twelve patients, of whom two had had this complication twice. Excluding pregnancies which ended in abortion (198), the total number of previous pregnancies was 1,796 . The incidence of placenta praevia in these pregnancies was therefore 0.56 per cent., and that of antepartum haemorrhage of unspecified type, in some cases almost certainly due to placenta praevia, was 0.78 per cent. Precise evaluation of risk of recurrence is not possible from these data, but it seems likely that women who have had placenta praevia are exposed in subsequent pregnancies to a risk somewhat greater than normal.

Part of this increased risk may be due to the fact that placenta praevia is now often treated by Caesarean section which, according to Bender (1954), may contribute to the likelihood of placenta praevia in a subsequent pregnancy. In the past, recurrence has rarely been reported. Fried and Torpin (1943) found only ten instances in the literature and added one further case. Irving (1936), reporting on 308 cases treated in the Boston LyingIn Hospital, found no instance of recurrence in the period 1916-34, but Aaberg (1946), working in the same hospital, recorded details of two recurrent cases. The fact that the present series which covers only an 11-year period contains five instances of recurrence within that period suggests that this phenomenon is becoming less rare. This may be due to the increasing frequency with which placenta praevia is treated by Caesarean section (Table V).

TABLE V

PERCENTAGE OF CASES OF PLACENTA PRAEVIA TREATED BY CAESAREAN SECTION

\begin{tabular}{|c|c|c|c|c|c|}
\hline \multirow{2}{*}{ Year } & \multicolumn{4}{|c|}{ Type } & \multirow{2}{*}{$\underset{\text { Types }}{\text { All }}$} \\
\hline & 1 & 2 & 3 and 4 & $\begin{array}{c}\text { Un- } \\
\text { specified }\end{array}$ & \\
\hline 1942 & $4 \cdot 7 \quad(43)$ & $26 \cdot 7(30)$ & $88.6 \quad(35)$ & $-(5)$ & $38.9(113)$ \\
\hline 1944 & $15 \cdot 1 \quad(53)$ & $26 \cdot 8$ (56) & $77 \cdot 8$ (36) & $-(3)$ & $35 \cdot 8(148)$ \\
\hline 1946 & $6.5 \quad(93)$ & $45 \cdot 7(81)$ & $91 \cdot 7 \quad(72)$ & $-(3)$ & $44 \cdot 6$ (249) \\
\hline 1948- & $\overline{18 \cdot 8 \quad(85)}$ & $54 \cdot 5(66)$ & $91.8 \quad(49)$ & $-(7)$ & $47 \cdot 8(207)$ \\
\hline $1950-52$ & $40 \cdot 4(114)$ & $48 \cdot 1 \quad(54)$ & $\overline{95 \cdot 1 \quad(82)}$ & $-(20)$ & $61 \cdot 1(270)$ \\
\hline$\overline{\text { Total }}$ & $20 \cdot 1(388)$ & $42 \cdot 5(287)$ & $90 \cdot 5(274)$ & $63 \cdot 2(38)$ & $47 \cdot 8(987)$ \\
\hline
\end{tabular}

Number of cases is given in brackets

It is perhaps worth recording the fact that four of the five patients who appear twice in this series and for whom detailed notes of the first incident are available were treated on both occasions by Caesarean section.

\section{Discussion}

This inquiry provides strong evidence of the influence of age on the incidence of placenta praevia. The association is particularly striking in the more severe cases, but is by no means restricted to central placenta praevia; it is firmly established for Type 2 cases, and even Type 1 shows a significant trend with age among primiparae. Parity does not appear to play any part in aetiology except possibly in Type I cases occurring in women aged 25-29. Errors in diagnosis are more likely in the less severe forms of the disease, and it is quite possible that the group classified as Type 1 contains a number of cases of antepartum haemorrhage not due to a low-lying placenta. If this is so, this group does not constitute a clinical entity and therefore may be expected to show the age-parity pattern of placenta praevia superimposed upon that of one or more other conditions. The evidence does not support the view that central placenta praevia is aetiologically distinct from the non-central type (Penrose, 1939; Kalmus, 1947), and it seems doubtful whether parity is of much importance even in the least severe cases. It is therefore unlikely that elucidation of the cause of placenta praevia will result from a consideration of the influence of previous pregnancies on the structure or function of the uterus (except perhaps in the special case where a previous pregnancy was terminated by Caesarean section). A study of the influence of age on the uterus seems to offer a more promising approach.

\section{SUMmARY}

(1) During the years 1942-52, 1,023 cases of placenta praevia were treated in Birmingham hospitals. Incidence in the general population was estimated to be 3.9 per 1,000 confinements.

(2) The incidence of cases of Type 2 and of Types 3 and 4 showed an increase with advancing age within each parity group; there was no association with parity when age was held constant. Type 1 showed a significant trend with age among primiparae and with parity for mothers aged 25-29; it is suggested that this pattern may be due to inclusion of some cases of antepartum haemorrhage due to other causes.

(3) No special study of fertility was attempted, but the age-parity tables do not suggest any abnormality in this respect. 
(4) The incidence of twinning was raised; this result is not unexpected and appears to be of little aetiological importance.

(5) Congenital malformations, especially anencephalus, occurred more frequently than usual. It is suggested that this observation may have some bearing on the slight excess of male foetuses in pregnancies complicated by placenta praevia.

(6) The abortion rate of previous pregnancies of patients with placenta praevia may be a little higher than that among mothers in the general population.

(7) The risk of recurrence appears to be greater than has hitherto been suspected. It is suggested that a possible factor is the increasing tendency to treat placenta praevia by Caesarean section.

I gratefully acknowledge my indebtedness to the staffs of the Birmingham maternity hospitals for permitting access to their records and to Miss Ida Giles and Miss Patricia Hobson for abstracting the data.

\section{REFERENCES}

Aaberg, M. E. (1946). Amer. J. Obstet. Gynec., 51, 578.

Aigner, K. (1940). Zbl. Gynäk., 64, 884.

Bender, S. (1954). Surg. Gynec. Obstet., 98, 625.

Binder, J. (1934): Amer. J. Obstet. Gynec., 28, 92.

Browne, F. J. (1937). "Antenatal and Postnatal Care", 2nd ed. Churchili, London.
Carter, C., and MacCarthy, D. (1951). British Journal of Social Medicine, 5, 83.

Davis, M. E. (1936). Amer. J. Obstet. Gynec., 32, 518.

-, and Campbell, A. (1946). Surg. Gynec. Obstet., 83, 777.

Eastman, N. J. (1950). "Williams Obstetrics", 10th ed. AppletonCentury-Crofts, New York.

Findley, D. (1951). Amer. J. Obstet. Gynec., 61, 855.

Fried, P. H., and Torpin, R. (1943). Ibid., 46, 444.

Greenhill, J.' P. (1923). Surg. Obstet. Gynec., 36, 227.

(1939). Amer. J. Obstet. Gynec., 37, 624.

Irving, F. C. (1936). Ibid., 32, 36.

Kalmus, H. (1947). Ann. Eugen. (Camb.), 13, 283.

Macafee, C. H. G. (1945). J. Obstet. Gynaec. Brit. Emp., 52, 313. McKeown, T., MacMahon, B., and Record, R. G. (1953). Amer. J. hum. Genet., 5, 168.

and Record, R. G. (1956). Ibid., 8 (in the press).

MacMahon, B., and McKeown, T. (1952). British Journal of Social Medicine, 6, 265.

- (1953). Amer. J. hum. Genet., 5, 176.

- and Record, R. G. (1953). Brit. Heart J., 15, 121.

Murphy, D. P. (1947). "Congenital Malformations", 2nd ed. Lippincott, Philadelphia.

Penrose, L. S. (1939). J. Obstet. Gynaec. Brit. Emp., 46, 645.

Record, R. G., and McKeown, T. (1949). British Journal of Social Medicine, 3,183.

Royal College of Obstetricians and Gynaecologists and British Paediatric Association Joint Committee (1949) "Neonatal Mortality and Morbidity". Reports on Public Health and Medical Subjects, No. 94. H.M.S.O., London.

Rizzuti, A. (1947). Arch. Ostet. Ginec., 52, 95

Shaw, W. (1947). "Textbook of Midwifery", 2nd ed. Churchill, London.

Smith, A., and Record, R. G. (1955). British Journal of Preventive and Social Medicine, 9, 51 .

Solomons, B., and Canter, H. E. (1932). Surg. Gynec. Obstet., 54, 790.

Tennent, R. A. (1947). Edin. med. J., 54, 510.

Waterhouse, J. A. H. (1950). British Journal of Social Medicine, 4, 197.

Wesselink, D. G. (1922). Zbl. Gynäk., 46, 2011.

Westgren, A. (1954). Acta obstet. gynec. scand., 33, 29.

Yates, F. (1948). Biometrika, 35, 176. 